\title{
NVivo based Al-Quranic features in students for autism therapy
}

\author{
Alexander Wiliams ${ }^{1}$, Adam Faturahman 2 ${ }^{2}$ Untung Rahardja ${ }^{3}$, Anggit Panji Pangestu ${ }^{4}$, \\ Fitra Putri Oganda ${ }^{5}$ \\ Queensland University ${ }^{1}$, University of Raharja ${ }^{2,3,4,5}$ \\ e-mail: a87.williams@connect.qut.edu.au 1 , adam.faturahman@raharia.info² \\ untung@raharja.info ${ }^{3}$, anggit.panji@raharja.info ${ }^{4}$, fitra.putri@raharja.info ${ }^{5}$
}

Wiliams, A., Faturahman, A., Rahardja, U., Oganda, F. P., \& Pangestuutomo, A. P. (2021). NVivo based Al-Quranic features in students for autism therapy. Aptisi Transactions on Technopreneurship (ATT), 3(1), 81-90.

DOI: https://doi.org/10.34306/att.v3i1.145

\begin{abstract}
In 2018, according to data from the CDC in America, it is estimated that 1 in 59 children prevalence (incidence rate) of children have Autism Spectrum Disorder, compared to 2014, which is 1 in 68 children increased by 15\%. The average boy often experiences unique symptoms, the problem is on the spectrum of neural development and can affect all sorts of aspects of learning, although many researchers focus on aspects of related issues but are measured to lack emphasis. So it is done on the learning of problems associated with religious education, read the Qur'an lovingly and also pray (șalāhn). Non-Arab speakers with autism, this study aims to characterize the natural characteristics displayed by a special student (autistic) in reading the Quran. To provide the same opportunity in carrying out their religious obligations, an 8-year-old boy from Malay with autism is already high, for a month with a session conducted three times the program was chosen as the subject. At least during the six months of Al-Quran lessons and he was able to communicate orally in class. NVivo software is useful for this analysis and it was found that every experimental session was recorded by audio by a digital camera and a digital camera visual voice recorder. the first chapter test includes reading the Quran (al-Fatihah) using five different types: (a) Malay Translation, (b and $c$ ) the complete set of chapters in Uthmani and Rasm Qiyasi races respectively, and ( $d$ and e) sets of disorganized and incomplete chapters in Uthmani rasm. Research Autistic individuals for the selection of appropriate recommended reading materials. Teachers and parents for effectiveness in studying the Quran need to be considered, This identifies the features that have been shown during the lessons of the Quran.
\end{abstract}

Keywords: Learning Programs, Autism, Quran, NVivo.

\section{Introduction}

The One True God has created and designed mankind to be citizens of various nations and races to know and appreciate, and pay attention to diversity. God almighty also destined a number of normative populations that they live in a state incapable of meeting their daily needs, because they differ physically and or emotionally.

Within the history of Islamic civilization There's a frame of accentuation on the story of particular lessons for and learning for individuals with incapacities (individuals with inabilities). Be that as it may, the choice was given to them in terms of the usage of the home of adore and law ('ulūm al-figh), for case, exemptions to the war as in Amr's story and limitations on the cover of the area taboo to be seen, with individuals connection with incapacities. But the story of Abdullah Ibn Maktum clearly reminds us that people with disabilities should not be marginalized by society. Ibn Maktum interrupted the discussion of the Prophet Muhammad and the Quraysh 
leaders with his question. Prophet Muhammad (saw) Appeared an expression of troubled. In any case, The One Genuine God censured the Prophet Muhammad for not being able to see the act Ibn Maktum who was daze seem not be annoyed by the prophet's activities (saw). Appears the disappointed expression of Prophet Muhammad (pbuh). Not being able to see this act, a dazzled Ibn Maktum may not be outraged by the Prophet (s). Be that as it may, God censured Prophet Muhammad (saw). Lively conveying information that's advantageous isn't as it were imperative for the wealthy and the control but moreover for the frail, the destitute and the marginalized society of others. Al Quran surah 'Abasa to allow an case to the individuals of Muhammad (saw) This letter goes down when the occasion happened.

Service of Instruction Malaysia's official site states Logic Instruction in Malaysia emphasizes all encompassing instruction to create an adjusted human, otherworldly, physical, mental and enthusiastic based on devout convictions. Muslims with uncommon needs get early introduction, particularly within the hone of adore (e.g., bathing and supplication) and the abilities of perusing the Qur'an utilizing modules, as in surah Iqra. J-QAF Islamic uncommon instruction (uncommon instruction integration program) has been actualized to guarantee that your students are in have to be illustrate the government's assurance that the potential of each student [1] is guaranteed and created in a entire and comprehensive way. Every Muslim student is given regular lessons for religious education by the government. Therefore, this amānah (task) is welcomed by the Muslim community [2] , including researchers who want to design [3] the best approach to apply in disability [4] classes about the lessons experienced.

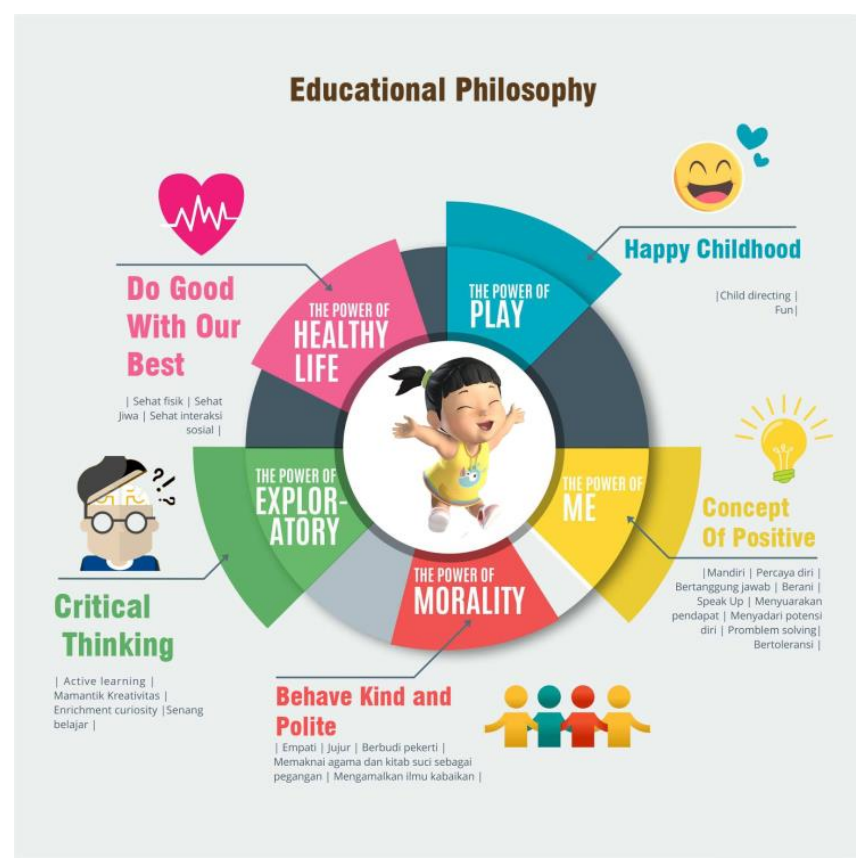

Figure 1. Educational Philosophy

One of the seven categories of persons with disabilities involves learning problems in understanding the individual concerned to decipher normative issues. The Department of Social Welfare defines one problem faced by per autistic person. In Arabic 'tawahhud' (Tafaol Centernd), it comes from the word 'tawahhada' which means 'exile/isolation' One of the terms autism in the sense of the word. DIn other words, from the characteristics of an autistic person including wanting to be alone all the time and having their own style of thinking, this is difficult for others to understand.

The term 'autism' was to begin with presented in 1943 by Leo Kanner, a therapist from John Hopkins Healing center, USA. Cars, which implies ' self' Historical underpinnings of the word comes from the Greek. The characteristic $k$ is comparative, for case talking alone, selfharm, and enthusiastic flimsiness. A few extreme introvertedness criteria moreover apply to the category 4 schizophrenia. This confirmation is bolstered by Burbach and Van der Zwaag detailing that extremely introverted people and schizophrenia have comparative hereditary variables that can disturb the brain's formative mechanisms. 
Autism develops in boys who are five times more likely to be diagnosed [5] with girls. Abnormal genetics involving structure chromosome $X$, is a factor why boys are more dominant in expressing symptoms of autism is a fragile syndrome $X$ with a genetic condition. Five of the symptoms shown were that the child did not show any reaction to mutual attention or pretend to play (theatrical). Characteristics of autistic children especially when it comes to making eye contact, lack of attention is also one of the factors.

Autism is one of the disorders on the spectrum of nervous system development, identified in a 3-year-old child. This involves problems in certain zones, including in learning. Four basic concerns during the learning process (Malaysia education policy 2013): reading, writing, counting and basic reasoning. Due to time constraints and learning syllabus, lack of attention to learning problems directly related to Islamic education. Al - Quran should be established for people with disabilities A special methodology for reading. Particular strategies for perusing the Koran ought to be built up for people with incapacities. Nongovernmental organizations (NGOs) were built up when a few to guarantee this specific bunch was not dismissed to be coordinated into the standard instruction system [6] framework, particularly in connection to Islamic instruction and standards in daily life. Among the NGO's purposes that have been set up for yayasan Pendidikan Al - Qur'an for Extraordinary Children (Establishment FAQEH).

The reading skills of Al - Qur'an should be taught from an early age to allow autistic people to at least read the surah al-Fatihah, because al-fatihah is a mandatory part of prayer (șalāh). This research [7] is about the learning of autistic individuals, relatively abandoned in reading Al - Qur'an.

This research [8] focuses on the reading process because it is fundamental in learning activities. For example, one can only complete one of the five pillars of Islam, such as praying, reading al-Fatihah when he can at least.

\section{Literature Review}

Research conducted by Eko Putro Widoyoko that is arranged to progress the instruction segment of the instruction program is called the instruction program. The course level regularly employs smaller scale assessment, in order to discover accomplishments particularly for understudy learning [9]. According to Indra Keswara expose Memorizing Al - Qur'an is exceptionally diverse from memorizing a word reference or book. Memorizing Al - Qur'an must be redressed in recitation and familiarity in presenting it. Memorizing Al - Qur'an could be an exceptionally respectable movement within the eyes of Allah SWT. If the memorizer of Al Qur'an cannot study and don't know the recitation, it'll be troublesome to memorize Al - Qur'an [10]. Research conducted by Muhammad Arobi expose Since the starting of instructing Al Qur'an until presently, there are numerous strategies utilized in learning Al - Qur'an. Jibril as a (talaqqî) and spelling (al-Baghdadiyyah) to present day ones such as the ummi, qiraati, and tartili strategies. This is often the result of the endeavors of researchers to develop methods of educating Al - Quran to form it simple, quick and fun [11] . According to Nur Maslikhatun Nisak expose Al-Qur'an at the rudimentary level may be an exceptionally unequivocal establishment for the success of improvement at an after arrangement within the character of learning efforts. Through the instruction of $\mathrm{Al}$ - Quran, it is vital to urge a more prominent need, considering the brilliant age of the improvement of the child's age is basic school and the period of improvement which incredibly decides character improvement within the following period [12]. Research conducted by Muyasaroh and Sutrisno expose an impressive source of lessons based on Al Quran which motivates great educating strategies on considering and inventiveness. Usually the position of $\mathrm{Al}$ - Quran so that its immaculateness and immaculateness are kept up [13].

Research conducted by Siti Patonah Mohamad, M. Y. Zulkifli Mohd. Yusoff, and Durriyyah Sharifah Hasan Adli expose Educating Al - Quran for children with mental incapacities (such as extreme introvertedness) is done by reporting it. Be that as it may, it is the request of all in guaranteeing that their right to peruse Al - Quran isn't ignored. In spite of the fact that the usage of any instructing strategy for this privileged class may be a troublesome matter [14]. Research conducted Nurhayati Syazwani Zulkafli, Latifah Abdul Majid, \& Hamdi Ishak exposeWe frequently see children with learning within the scholastic field as contradicted to learning the uncommon Koran more likely with scholastic learning. From the point of learning of 
Al - Quran, this extraordinary child moreover has the same rights as other commonplace children. Like a normal child since Al - Quran was uncovered to all levels of society, counting special children. They too have to be instructed to study and live Al - Quran [15]. Research conducted by Dwi Cahya Marliani expose The comes about of the ponder appeared an increment in net and fine engine action in children with extreme introvertedness within the Sragen Extreme introvertedness Benefit Center. Extremely introverted action in children with hyperactive behavior and withdrawal has diminished after being given murattal treatment. Approximately the impact of sound wall paintings on the advancement of behavior of children with extreme introvertedness. In the interim, the investigation will proceed to be examined. There was a noteworthy increment within the improvement of behavior of children with extreme introvertedness after being given Al-Quran sound murattal treatment [16]. Research conducted Dewi, Nur Fadiana expose So distant, learning Islamic devout strategy is connected to religion Still within the ancient (conventional) ways such as addresses, revere homes that appear dry to memorize and shows. Such strategies are as a matter of fact bored, bored, and missing eagerness in examining religion [17]. Research conducted Ria Susantia, Syafrimen Syafrilb, Rifda El Fiahc, Titik Rahayu exposeMulti-case single-site case ponder plan could be a sort of case ponder investigate (case consider test design), to be specific inquire about is carried out employing a subjective approach. The utilize of the case consideration permits the analyst to get an assortment of in-depth data related to what is being examined on the issue. Information was collected through perception, interviews, and instructors including NVIVO 10 apps.

\section{Research Methodology}

Research follows the right standards for research involving human subjects, to ensure that protocol, ethical consent can be obtained. Written permission from the parents concerned also before the research [18] begins. Used an interview script for parents, surah al-Fatihah for reading test sessions, as an instrument of qualitative studies (ethnography). Before the subject participates regarding the reading test session the parents are interviewed first.

\section{Results and Discussion}

\subsection{Subject / Participant}

Being the subject in this study of an 8 year old boy, he was an Islamic elementary school student. His teacher and mother were interviewed to record his health and education [19]. Criteria / requirements characteristic of the subject selected non random sampling, for example : (1) Officially by doctors diagnosing the subject as a high functioning autism sufferer under payment ASD (Autism Spectrum Disorder), with good communication skills. and cognitive function, (2) The subject read the Al - Quran for 6 months and had exposure to Al - Quran education [20] from the age of 6 year. (3) the subject is able to communicate verbally.

\subsection{Instruments}

Five forms of al-Fatihah were used [21] in each test session. Each set is printed: (a) AlFatihah Malay interpretation Utilizing the Latin letter set, (b and c) the total al-Fatihah script within the Uthmani rasm and the Qiyasi rasm, individually, and ( $d$ and e) the al-Fatihah script within the inadequate and disorganized Uthmani rasm. The works of al-Fatihah in this study [22] were compiled by trading the composing fashion of each Hassock and Qiyasi rhyme to the 'Qur'an in Word' app utilized in Microsoft Word. Each test session was recorded sound outwardly employing a digital [23] camera and voice recorder. The coding and learning are handled by the NVivo program for facilitation.

\subsection{Prosedure}

The test session is conducted after obtaining permission from the parents and the school administration. In order to know that he would feel comfortable with the researcher, the first test session was conducted. The subject is introduced by the teacher to the researcher, these kinds of tests are very important. To avoid any disharmonious situations during the session. Previously, researchers attended classes for people with autism in a facility for people with disabilities for a year, to ensure that researchers could interact well with people with autism. Conducted every face-to-face test session between the researcher and the subject in a closed room at the selected school. all test sessions use the same place. Researcher, research [24] 
assistant, and subjects who are in the room during each test. Before starting the test, the researcher will ensure a good social interaction with the subject, for example, greeting him by asking how he feels, asking how the day was and reading the prayer (prayer) test before being together. Subjects were given a set of copies consisting of five different characters in the form of al-Fatihah print. Set aloud when the subject started reading and counted the time. Using audio-visuals each reading test takes between 20 and 30 minutes, the pre-recorded test is conducted three times a week for four weeks, unless the subject is unable to attend due to unavoidable situations, eg health [25] problems test 20 minutes each morning for an 8 week duration intervention process. The subject's perusing term amid the consider was compared to the standard al-Fatihah recitation by ten world popular reciters (qārī) gotten from the site, which combines readings by Rahman Al-Sudais, Saad al-Ghamidi, Mishary Rashid Alafasy, Abdelbasset Abdessamad, Ahmed Al- Ajmi, Maher Al Mueaqly, Tarif Abbad, Omar Al Kazabri and Mohamed Seddik El Menchaoui (see Assabile nd). The normal length of their recitation was 36.5 seconds. A special protocol was used during this study. First, prepare audio-visual equipment by the researcher before inviting the subject into the room. When each subject is comfortable the test can only be started. Each session begins by inviting the subjects to read a special prayer together (du'ā) for learning activities. Some commonly asked social problems, for example, what day was it? During the test, subjects were asked to read each set that was given. The timing was recorded as before long as the subject begun recounting al-Fatihah. The subject was moreover inquired to appear or appear the verses that were studied from each original copy with his fingers. In the event that the subject does not carry on in agreement with the informational, the analyst will at that point utilize a gadget to hold on to the student's palm or wrist (hand stabilization strategy) and educate the subject to move his fingers. Each time the subject completes the errand, the analyst will laud him with sentences such as' work great, 'without giving him any physical gifts.

\subsection{Discussion}

The characteristics of autistic students during the learning session to read the Al-Quran, as well as writing the Al-Quran typography in accordance with the autistic person. Two main findings were obtained from the preliminary study. There are no physical prizes offered during the reading process (food / games).

\subsection{Research Implementation}

After determining the problem and how to solve it, you can write down the results of your implementation, which is explained theoretically descriptions, both qualitatively and quantitatively which can be in the form of graphics, images, diagrams, and others that make the reader easy to understand

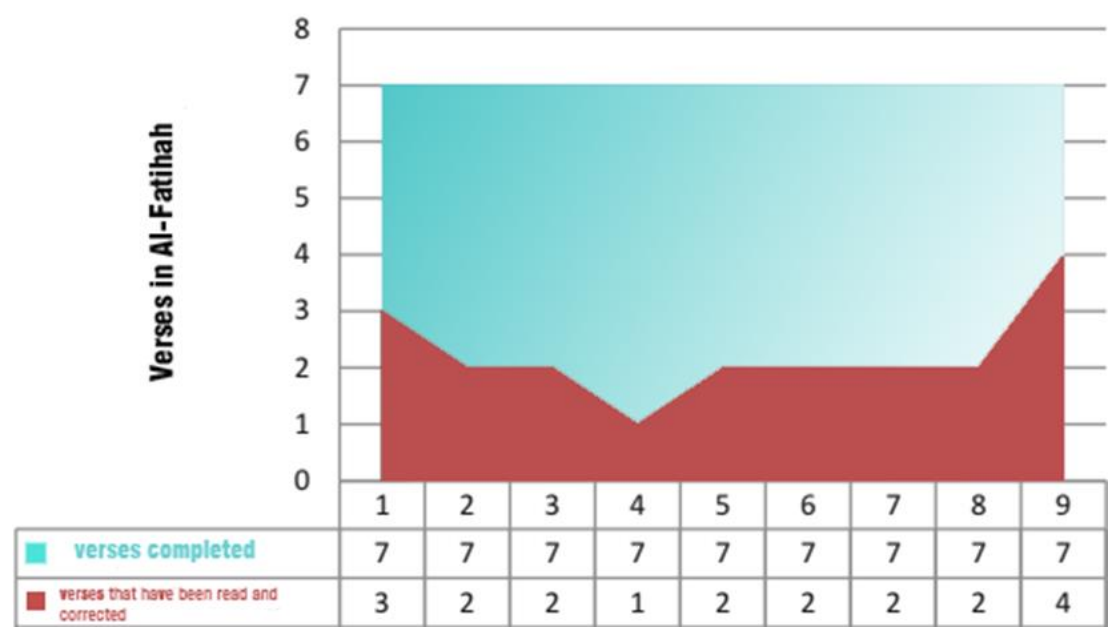


Day

\subsubsection{Privileges Reading Al-Fatihah}

Figure 2. The reading of al-Fatihah in an irregular form

The process of reading aloud requires focus and concentration as well as the ability to visual feedback input to voice the reading. Reading skills that involve short-term memory will develop into memorization skills that involve long-term memory after getting used to reading. From interviews with mothers and teachers, subjects can read what the researchers [26] know. The characteristics shown by the subject during reading include memorization, divided attention, the influence of the mother tongue on foreign languages and being influenced by writing style (typography).

\subsubsection{Memorize}

The subject displays Al-Fatihah memorized abilities. This is evidenced by being asked by the subject for writing that is indicated by certain verses in al-Fatihah and their readings. The verses are completely different from what he shows the subject while reading. Usually, the verses that he showed were the verses before the verses that were read; that is, the reading is faster. More significant evidence that rote memorization beats the reading ability of a student [27] is shown when he is asked to read Himpunan (d), namely Al-Fatihah and its irregular form. Subjects were able to read correctly only four of the seven verses during the test (Figure. 2). Similar results were obtained when it involved reciting the Himpunan (e), which had the verses from Al-Fatihah in incomplete form (Figure. 3).

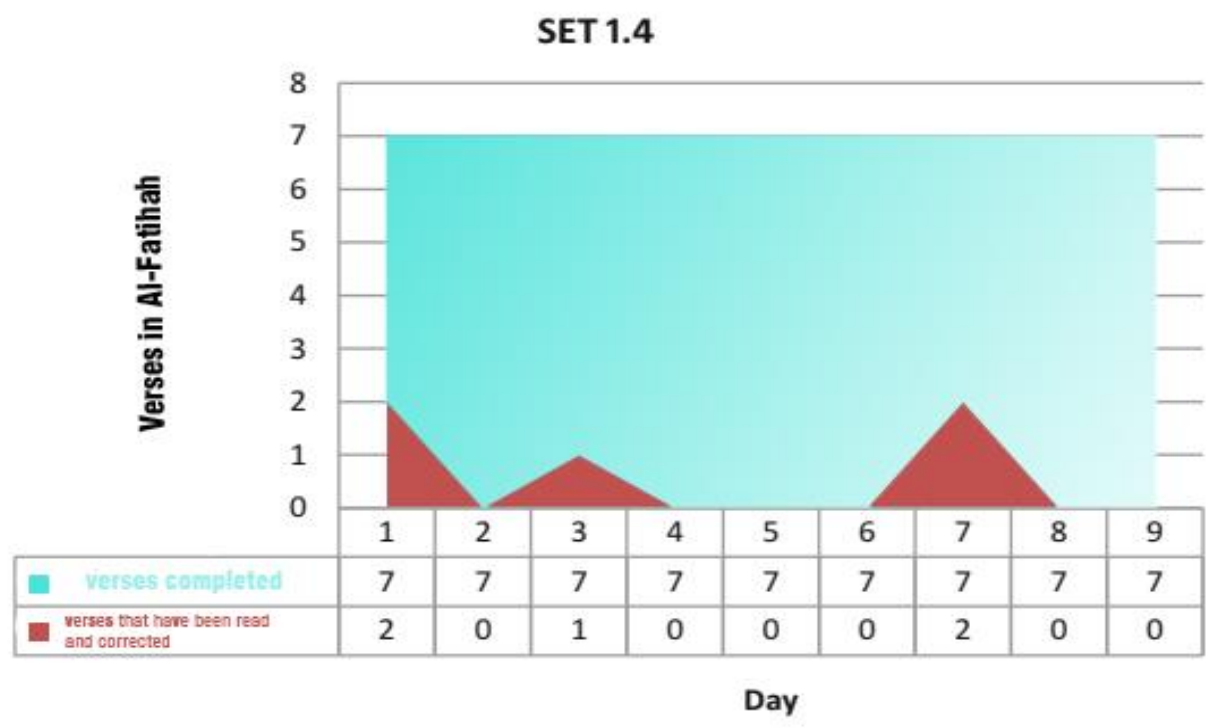

Figure 3. The results of the reading of Al-Fatihah in the form of irregular collections

\subsection{Psychology from an Islamic Perspective}

Certain Physical Parameters used to understand a person's thinking are problems that cannot be measured. But the potential of human thinking through its behavior can be tested. Like Plato and Aristotle and also mentioned in the Qur'an, Knowledge of the soul / spirit is much debated by western philosophers.

\subsubsection{Concept of Soul / Spirit}

Psychology from the Islamic Perspectives from Dr. Aisha Utz conveyed that human creation from a secular world view is very different from the Islamic concept. Seeing the combination of biological functions of the brain such as cognitive, emotional and behavioral elements is Islam which adopts theological and metaphysical concepts. Therefore, the state of the individual soul / spirit will influence the direction of his thoughts, feelings, and behavior which 
is defined by humans as a vehicle that is moved by the soul / spirit. His zeal is mentioned in Al - Qur'an:

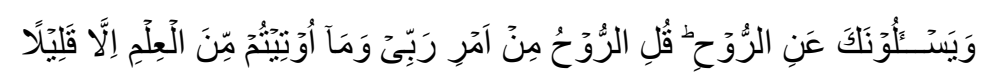

And they ask you, Muhammad, about spirits. Say, "Zeal is my business sir. And mankind has not been given knowledge except a little.". (Q. Al - Isra 17:85)

In this way, the capacity to induce along well with others depends on common understanding between people. People were made to complement each other, have a wide understanding of how one can live in bunches and react as 'empathy' which is pertinent to others is known. Sympathy does not as it were include the integration of the forms of the frontal cortex but moreover the midbrain and brainstem to control feelings, body physiology and action. This preparation is exceptionally imperative in learning exercises. Past ponders have alluded to the 'empty' considering fashion in extremely introverted people as 'mind power'. This alludes to the mental state of an extremely introverted person. people who cannot get it the situation or the encompassing environment. Typically one of the components that adversely influences their relationship with those around them, gatekeepers, family individuals, instructors or gatekeepers, notwithstanding of whether they are strangers. However, it is human nature that in any case of whether an individual may be normative.

\subsubsection{Psychology of Reading}

Instructions for reading or voicing written or unwritten documents, The term lqra 'in Arabic. Judging from certain documents, this is different from the term utlu which means reading in context. Please read that the ability to extract visual information [28] from a page and understand the meaning of the text is expressed from the Psychology of Reading Book. There is still controversy about how the information [29] obtained actually processes a person. The most established is the point of view, recently reported by Rayner et al., That there are three stages in how this process occurs: sensory storage, short-term memory 8 and long-term memory. 10 Difficulty reading Al - Quran is categorized as a learning problem for persons with disabilities, such as individuals with autism. From an Islamic point of view, Al - Quran will produce results both in the world of life and in the hereafter, only by reading the Al - Quran. Even more rewards will be for those who have difficulty reading, for example people with autism who experience difficulties even in the learning process about reading Al - Quran as stated in Saheeh Muslim:

Al - Quran when read beautifully, fluently, and accurately, someone who reads it will be accompanied by noble and obedient angels. Indeed, a person who reads and recites with difficulty, he will have twice the reward like stuttering or stumbling over a verse. brother read linguistic studies that would allow one to understand a particular language. Listening to and decoding words 11 Reading performance are the two main components. Listening to and understanding words and then turning them into written or spoken (verbal) material is a complex activity. Al - Quran in Arabic by non-Arabic speaking subjects with autism in the context of reading, there are other factors that are related: (1) the design of composing the dialect (typography), (2) the capacity to studied Arabic (a outside dialect), and (3) perusing varieties of words, correct words and words that have the same elocution, but have a particular meaning (pseudo homophones), and words that have the same elocution but have no meaning (pseudoword). However, it is human nature that in any case of whether an individual could be normative.

\subsubsection{Autism Awareness}

Autism is an individual minority group. However, as reported by the US Centers for Disease Control and Prevention, the percentage of autism has been increasing. Autism awareness continues to increase, as reflected in the many activities related to autism organized by several non-governmental organizations who know about this disorder and there are still some people who do not know about this disorder. For illustration, realizing a issue with her child, the mother of the consider subject considered the development [30] of her child to be to 
some degree late since the mother of the subject considered her child's generally late improvement was typical (meet interpretation): (In the event that I'm not mixed up, her one year ancient sister can conversation, for illustration: "Mother, my things have fallen." When I inquired about my mother, she said, "That's ordinary, a few kids are so moderate." four a long time, I feel his improvement is as well moderate. He can't get my information. For illustration, he can't indeed get it on the off chance that I get it, inquiring him to require his bottle of drain. I think it's crazy for a four year ancient boy. Not talking is one thing. thing, but not understanding the informational is another thing ... But my mother still said, "It's typical for kids to be moderate ...")

\subsubsection{Awareness of Al - Quran Learning for Persons with Disabilities}

Community activities such as instructors and concerned guardians in creating strategies to guarantee that people with disabilities (extreme introvertedness) are not impeded in devout instruction. The significance of mindfulness of devout instruction for extremely introverted people is additionally picking up acknowledgment within the Muslim community, in spite of the fact that as it were as a notice at slightest for individuals with other incapacities. For case, the part of the Malaysian Islamic Understanding Established (IKIM) is exceptionally vital in dispersing current devout issues related to individuals with disabilities, (for case, conducting devout administrations and devout homes) through electronic media and logical discourses. Muslim scholastics have too begun to contribute to this goal in terms of thinks about being carried out to help people with incapacities, especially the daze and hard of hearing, in cultivating learning Al - Quran.

\section{Conclusion}

The discoveries of the think about demonstrate that the favored sort of perusing fabric ought to be chosen for extremely introverted people to utilize as well as distinguish person highlights that ought to be carefully considered in order to extend the viability of Quranic learning for them. For instructors and guardians of extremely introverted people this data can be valuable. It appears that the subject is able to study al-Fatihah composed in Uthmani rasm smoothly compared to the form composed within the Qiyasi rhyme. It is proposed that the Mushaf of the Quran with a longer separate between words (sentences) or a bigger column width would be more reasonable for extremely introverted people. Encourage investigation is required since the current research [31] is as it were a trial including one subject.

\section{Acknowledgments}

God Almighty, to Alphabet Incubator, and Raharja University who have fully supported this research [32], We would like to thank you. And to the Alphabet Istiqlal has developed in this article as a concrete form of science and technology which is taken based on the provisions of the Qur'an for good in the future.

\section{References}

[1] S. Sudaryono, Q. Aini, N. Lutfiani, F. Hanafi, and U. Rahardja, "Application of Blockchain Technology for iLearning Student Assessment," IJCCS (Indonesian J. Comput. Cybern. Syst., vol. 14, no. 2, pp. 209-218.

[2] A. Muhtadibillah, H. T. Sukmana, and N. F. Rozy, "An Evaluation Of Helpdesk With Gamification Using Indeks Kepuasan Masyarakat (IKM)," IAIC Trans. Sustain. Digit. Innov., vol. 1, no. 1, pp. 8-17, 2019.

[3] N. Lutfiani, F. P. Oganda, C. Lukita, Q. Aini, and U. Rahardja, "Desain dan Metodologi Teknologi Blockchain Untuk Monitoring Manajemen Rantai Pasokan Makanan yang Terdesentralisasi," InfoTekJar J. Nas. Inform. dan Teknol. Jar., vol. 5, no. 1, pp. 18-25, 2020.

[4] R. Hardjosubroto, U. Rahardja, N. Anggraini, and W. Yestina, "Penggalangan Dana Digital Untuk Yayasan Disabilitas Melalui Produk UMKM Di Era 4.0," ADI Pengabdi. Kpd. Masy., vol. 1, no. 1, pp. 1-13, 2020.

[5] D. Susilawati and D. Riana, "Optimization the Naive Bayes Classifier Method to diagnose diabetes Mellitus," 2019.

[6] C. S. Lee, J. W. Wong, and P. Y. Ee, "Gamified mathematics practice: Designing with ecommerce and computational concepts.," 2017.

[7] M. Aziz and M. Aman, "Decision Support System For Selection Of Expertise Using 
Analytical Hierarchy Process Method," IAIC Trans. Sustain. Digit. Innov., vol. 1, no. 1, pp. 49-65, 2019.

[8] P. A. Sunarya, Q. Aini, A. S. Bein, and P. Nursaputri, "The Implementation Of Viewboard Of The Head Of Department As A Media For Student Information Is Worth Doing Final Research," ITSDI J. Ed., vol. 1, no. 1, p. 18, 2019.

[9] A. Rifandi, "Mutu pembelajaran dan kompetensi lulusan Diploma III Politeknik," Cakrawala Pendidik., no. 1, p. 87706, 2013.

[10] I. Keswara, "Pengelolaan Pembelajaran Tahfidzul Qur'an (Menghafal Al Qur'an) Di Pondok Pesantren Al Husain Magelang," Hanata Widya, vol. 6, no. 2, pp. 62-73, 2017.

[11] M. Arobi, "Rumah-Rumah Tahfizh di Kota Banjarmasin: Profil, Program, dan Metode Pengajaran Al-Qur'an," Tarb. J. IIm. Kependidikan, vol. 8, no. 1, pp. 39-52, 2019.

[12] N. M. Nisak, "Implementasi Kurikulum Pembelajaran Al Qur'an di Sekolah Dasar," Halaqa Islam. Educ. J., vol. 2, no. 2, pp. 150-164, 2018.

[13] M. Muyasaroh and S. Sutrisno, "Pengembangan Instrumen Evaluasi CIPP Pada Program Pembelajaran Tahfiz Al-Qur'an Di Pondok Pesantren," J. Penelit. dan Eval. Pendidik., vol. 18, no. 2, pp. 215-233, 2014.

[14] S. P. B. Mohamad, Z. B. M. Yusoff, and D. S. B. H. Adli, "Pengajaran dan pembelajaran al-Quran bagi golongan kelainan upaya mental: Analisis dari sumber tradisi Islam," $J$. Islam dan Masy. Kontemporari, vol. 8, pp. 153-168, 2014.

[15] N. S. Zulkafli, L. A. Majid, and H. Ishak, "Inovasi Perubatan Melalui Terapi al-Quran Terhadap Kanak-Kanak Autisme," AL-TURATH J. AL-QURAN AL-SUNNAH, vol. 3, no. 2, pp. 40-45, 2018.

[16] D. C. Marliani, "PENERAPAN AUDIO MURATTAL DALAM PEMBELAJARAN UNTUK MENINGKATKAN ATENSI ANAK AUTIS." UNNES, 2019.

[17] U. Raharja, N. Lutfiani, I. Handayani, and F. M. Suryaman, "Motivasi Belajar Mahasiswa Terhadap Metode Pembelajaran Online iLearning+ Pada Perguruan Tinggi," SISFOTENIKA, vol. 9, no. 2, pp. 192-202, 2019.

[18] P. A. Sunarya, A. Saptoro, and Z. Peh, "Utilization Setting Menu To Build Company Accounting System In Web Based Accounting Online System," Aptisi Trans. Manag., vol. 1, no. 1, pp. 1-10, 2017.

[19] Q. Aini, A. Badrianto, F. Budiarty, A. Khoirunisa, and U. Rahardja, "Alleviate fake diploma problem in education using block chain technology," J. Adv. Res. Dyn. Control Syst., vol. 12, no. 2, pp. 1821-1826, 2020.

[20] Q. Aini, T. Hariguna, P. O. H. Putra, and U. Rahardja, "Understanding how gamification influences behaviour in education," Int. J. Adv. Trends Comput. Sci. Eng., vol. 8, no. 1.5, pp. 269-274, 2019.

[21] A. Suryadi, P. T. Asmoro, and A. Solihin, "Hybrid Electric Power Plant Using Wind Turbine Savonius Helix and Solar Cell as an Alternative Power Source in the Lightning Tower at Flashing Lights," ADI J. Recent Innov., vol. 1, no. 1, pp. 1-6, 2019.

[22] U. Rahardja, T. Hariguna, and Q. Aini, "Understanding the Impact of Determinants in Game Learning Acceptance: An Empirical Study.," Int. J. Educ. Pract., vol. 7, no. 3, pp. 136-145, 2019.

[23] I. Amsyar, E. Christopher, A. Dithi, A. N. Khan, and S. Maulana, "The Challenge of Cryptocurrency in the Era of the Digital Revolution: A Review of Systematic Literature," Aptisi Trans. Technopreneursh., vol. 2, no. 2, pp. 153-159, 2020.

[24] K. Mergu, "Performance Analysis of Reed-Solomon Codes Concatenated with Convolutional Codes over AWGN Channel," APTIKOM J. Comput. Sci. Inf. Technol., vol. 1, no. 1, pp. 27-32, 2016.

[25] R. Geethanjali, "Notice of Retraction Survey on Health Monitoring of Elderly Using loT," Aptikom J. Comput. Sci. Inf. Technol., vol. 2, no. 3, pp. 131-136, 2017.

[26] R. B. Putra, F. Yeni, H. Fitri, and D. J. Melta, "The Effect Of Board Of Commissioners Ethnic, Family Ownership And The Age Of The Company Towards The Performance Of The Company LQ45 Company Listed In Indonesia Stock Exchange," ADI J. Recent Innov., vol. 1, no. 2, pp. 85-92, 2020.

[27] A. G. Prawiyogi and R. A. Toyibah, "Strategi Peningkatan Kompetensi Mahasiswa Melalui Model Sertifikasi Kompetensi," ADI Bisnis Digit. Interdisiplin J., vol. 1, no. 1, pp. 
78-86, 2020.

[28] U. Rahardja and E. P. Harahap, "Implementation of Information Planning and Strategies Industrial Technology 4.0 to Improve Business Intelligence Performance on Official Site APTISI," in Journal of Physics: Conference Series, 2019, vol. 1179, no. 1, p. 12111.

[29] S. Santoso, J. Kauf, and N. C. Aristo, "The Information System of Name Card Sales Based on Digital Marketing to Improve Creativepreneur on College E-Commerce Website," Aptisi Trans. Technopreneursh., vol. 1, no. 1, pp. 64-72, 2019.

[30] S. Kosasi, "Karakteristik Blockchain Teknologi Dalam Pengembangan Edukasi," ADI Bisnis Digit. Interdisiplin J., vol. 1, no. 1, pp. 87-94, 2020.

[31] M. B. Djatmiko, A. Husain, G. Maulani, and L. Nirmalasari, "Analyze and Record a Series of Corporate Sales Transactions On Web Based Accounting Online System," Aptisi Trans. Manag., vol. 1, no. 2, pp. 103-115, 2017.

[32] I. Handayani, U. Rahardja, E. Febriyanto, H. Yulius, and Q. Aini, "Longer Time Frame Concept for Foreign Exchange Trading Indicator using Matrix Correlation Technique," in 2019 Fourth International Conference on Informatics and Computing (ICIC), 2019, pp. $1-5$. 